\title{
'FATHER' IMAGERY IN 2 CORINTHIANS 1-9 AND JEWISH PATERNAL TRADITION
}

\author{
Anthony A. Myrick
}

\begin{abstract}
Summary
The metaphor of 'father' played a significant role in the pastoral practice of Paul. There is evidence that a major line of Paul's use of paternal imagery can be reliably traced back into the Old Testament and early Jewish tradition, namely the correction of his converts in 2 Corinthians 1-9. This finding suggests that Paul appears to owe much more to his ancient Jewish environment for his use of the paternal metaphor than has often been assumed, and sheds light on the nature and importance of Paul's fatherly correction in his pastoral care of the Corinthian community.
\end{abstract}

\section{Introduction}

From where did Paul derive his understanding and use of his fatherly role for his pastoral practice? Ernest Best is pessimistic in answer to this question and concludes: 'It is impossible... to determine from where Paul derived the image [of fatherhood] in relation to himself ${ }^{\prime}{ }^{1}$ In contrast, A.J. Malherbe is more optimistic, and advocates the background of the moral philosophers in the Greco-Roman world as the proper antecedent for understanding his familial role of father, as well as nurse in 1 Thessalonians. ${ }^{2}$ Different still is E.M. Lassen's of imperial propaganda in Greco-Roman tradition to

${ }^{1}$ E. Best, Paul and His Converts (Edinburgh: T. \& T. Clark, 1988) 35. Best's conclusions may be premature. He devotes less than four pages (32-35) to a discussion of possible antecedents for his pastoral familial roles.

${ }^{2}$ A.J. Malherbe, Paul and the Thessalonians: The Philosophic Tradition of Pastoral Care (Philadelphia: Fortress, 1987) 58; idem, 'Gentle as a Nurse: the Cynic Background to 1 Thess. 2', NT 12 (1970) 203-17. 
shed light on Paul's use of the father concept in 1 Corinthians $4: 14-21 .^{3}$

Lacking in all this is any consideration of the Old Testament and Jewish paternal tradition as a potential source or influence on Paul's use of the metaphor 'father'. That this Jewish background exerted some influence on Paul is nonetheless likely, in view of two initial factors: (1) Scripture and Jewish traditions seem to have played a significant role in shaping Paul's thinking in general, 4 and (2) the 'father' metaphor seems to have had some currency already in early Christianity, such as in Hebrews 12:5-6, where the metaphor is supported by a Scriptural citation. Our short study, therefore, will analyse the possibility that Paul may have been dependent upon Scriptural and early Jewish sources for his understanding and administering of fatherly correction or discipline in his pastoral work. ${ }^{5}$ Looking particularly at 2 Corinthians 1-9, we hope to show that Paul's vocabulary echoes the Jewish sapiential tradition, and that this tradition provides for a closer and more adequate background for Paul's use of the father metaphor than those currently on offer.

\section{Old Testament Material}

The picture of fatherhood painted in the Old Testament is especially one of giving direction. As is the case with 2 Corinthians, direction in Old Testament material was often provided by a father through the function of correcting his children. The discipline or correction given by sapiential

\footnotetext{
${ }^{3}$ E.M. Lassen, 'The Use of the Father Image in Imperial Propaganda and 1 Corinthians 4:14-21', TynB 42.1 (1991) 127-36.

${ }^{4}$ See, most recently, R.B. Hays, Echoes of Scripture in the Letters of Paul (New Haven: Yale, 1989); C.A. Evans and J.A. Sanders (eds.), Paul and the Scriptures of Israel (JSNTS 83; Sheffield: Sheffield Academic Press, 1993).

${ }^{5}$ Two other roles described in the Old Testament and early Judaism that have important pastoral connotations include: (1) the supportive role of a mother; (2) the reciprocal role of a brother. The presence of these two familial roles in 2 Corinthians will be explored fully in the author's forthcoming Ph.D. thesis, 'Paul's Pastoral Practice against its Jewish Background' (University of Aberdeen).
} 
leaders as fictive fathers, for instance, is a prime example (Pr. $1: 8 ; 4: 1 ; 6: 20 ; 15: 5 ; 30: 17) .{ }^{6}$ These father-like sages make frequent reference to the need to 'correct with care' (Pr. 13:24), to give 'reproof' $(1: 25 ; 10: 17)$ and to 'rebuke openly' $(27: 5)$ their spiritual children with a 'rod for discipline' (22:15; cf. Pr. 10:13; $23: 13,14) .{ }^{7}$ This right to discipline is founded on the premise that fathers (whether fictive or otherwise) were to be obeyed. So, for instance, we read: 'A wise son is obedient to his father, but a disobedient son will be chastised severely' (Pr. 13:1; cf. $15: 5 ; 29: 15 ; 30: 17)$.

Furthermore, the discipline of spiritual children by figurative fathers was seen to be a vital part of how the father figure, as pastoral leader, was to love members of their communities. Thus, Yahweh is compared to a caring father8 and said to 'correct those he loves' and 'scourge every son whom he receives' (Pr. 3:12). This analogy of Yahweh's care as a father who rebukes in love becomes personalised in his relationship with King Solomon: 'I will be a father to him and he will be a son to Me; when he commits iniquity, I will correct him with the rod of men and the strokes of the sons of men' (2 Sa. 7:14; cf. Dt. 8:5; 32:6, 19; Mal. 1:6; 2:1-3).

\section{Jewish Material}

Many Jewish pastoral leaders during the Second Temple period build on this Scriptural tradition and, in their pastoral task of correcting and disciplining their disciples, make use of the father/child imagery. ${ }^{9}$ For example, rabbis are depicted as

${ }^{6}$ C.R. Fontaine, 'The Sage in Family' in J.H. Gammie \& L.G. Perdue (eds.), The Sage in Israel and the Ancient Near East (Winona Lake: Eisenbrauns, 1990) 161; J.L. Crenshaw, 'The Sage in Proverbs' in The Sage in Israel, 212.

${ }^{7}$ On the parental discipline of adult children within sapiential groups, see G. Bertram, ' $\pi \alpha \imath \delta \varepsilon v \omega^{\prime}$ in G. Kittel and G. Friedrich (eds.), Theological Dictionary of the New Testament (Vol. V; Grand Rapids: Eerdmans, 1967) 608-10.

8For a discussion on Yahweh as a father, see A.H. de Boer, Fatherhood and Motherhood in Israelite and Judaean Piety (Leiden: Brill, 1974).

${ }^{9}$ On fatherly discipline in Early Judaism, see R. de Vaux, Ancient Israel

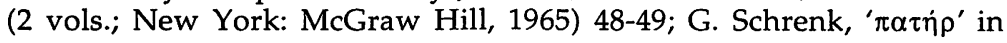


spiritual fathers (m. Mak. 2:3; m. Ed. 1:4; m. B.M. 2:11; Sifre Deut. $6: 7 ;$ b. Sanh. 19b) 10 and, on the basis of the Scriptural wisdom tradition, confront and correct their disciples (b. Arak. 16b). The Qumran group also adopts the paternal tradition and likens the role of its pastoral leaders to that of a father $(1 \mathrm{QH}$ 7:20-2; CD 13:9) ${ }^{11}$ who is obligated to 'correct' and 'test' his erring children (1QS 7; 8:21-24; $1 \mathrm{QH} 2: 13-14 ; C D$ 14:1). Finally, in the Psalms of Solomon, God's discipline of the righteous is like that of a father for his 'beloved son' (Pss. Sol. 13:7-10; 18:3$4,7)$.

This pastoral function of discipline did not involve a harsh and condemnatory spirit but, paralleling in the Biblical tradition, was motivated out of love and mercy. This is especially seen in a passage like Wisdom of Solomon 11:9-10 (cf. 1QH 9):

For when they were tried, though they were being disciplined in mercy, they learned how the ungodly were tormented when judged in wrath. For you did test them as a father does in warning, but you did examine the ungodly as a stern king does in condemnation.

In addition to this divine example of correcting in mercy, according to Philo Moses 'corrects' his 'true-born sons' not abusively but as 'a very kindly disposed father' (Vita Mos. 1:328). Moreover, the sapiential author of Sirach writes as a fictive father (Sir. 3:1; cf. 2:1; 4:1; 7:1) and speaks of the need to 'discipline', 'whip often' and 'take pains' with one's spiritual 'sons',12 nonetheless emphasising that the motivation for this discipline is love.

Kittel and Schrenk, Theological Dictionary, 945-59, 974-1022; Bertram, ' $\pi \alpha \mathrm{t} \delta \varepsilon v \omega^{\prime}$, 618; Best, Paul and His Converts, 33, 57.

10S.J.D. Cohen, From the Maccabees to the Mishnah (Philadelphia: Westminster, 1987) 121-2.

11O. Betz, 'Die Geburt der Gemeinde durch den Lehrer', NTS 3 (1957) 314-26; G. Vermes, The Dead Sea Scrolls in English (3rd ed.; London: Penguin Books, 1987) 10-12.

12R. Gordis, Poets, Prophets, and Sages: Essays in Biblical Interpretation (London: Indiana UP, 1971) 163-65. 
He who loves his son will whip him often, in order that he may rejoice at the way he turns out. He who disciplines his son will profit by him... Discipline your son and take pains with him, that you may not be offended by his shamelessness (Sir. 30:1-2, 13).

\section{Paul}

The concept of fatherhood played an important role in Paul's own pastoral practice. ${ }^{13}$ In keeping with Jewish paternal tradition, Paul frequently employs the father/child imagery to depict certain aspects of his pastoral care, either in connection with a community as a whole or with individual converts in particular. This can be demonstrated from across the Pauline corpus. Paul exhorts, encourages and implores the Thessalonians 'as a father would his own children' (1 Thes. 2:11). Paul clarified to the Corinthians that they 'might have thousands of guardians in Christ, but not more than one father and it was I who begot you in Christ Jesus' (1 Cor. 4:15). Paul continues this father/child imagery by exhorting the Corinthians, whom he addresses as his children (1 Cor. 4:14), to imitate him (4:16). He explained to the Philippians how Timothy had served with him in the furtherance of the gospel 'like a child serving his father' (Phil. 2:22; cf. 1 Cor. 4:17). With the same father imagery of begetting used in Corinth, Onesimus is referred to as Paul's 'child, whom I have begotten in my imprisonment' (Phm. 1:10).

More to the point for our purposes of considering the relationship of Old Testament and Jewish paternal traditions to 2 Corinthians 1-9 is 1 Corinthians $4: 21$. Proceeding as a spiritual father (1 Cor. 4:15), and in ways that recall imagery of the paternal 'rod ( $\dot{\alpha} \alpha \delta \delta \varsigma)$ for correction' in Proverbs 22:15 and 2 Samuel 7:14, in 1 Corinthians 4:21 Paul warns his converts of his authority to discipline them if necessary: 'Shall I come to

\footnotetext{
13For a discussion on Paul's use of father imagery in his pastoral practice, see P. Beasley Murray, 'Paul as Pastor' in Dictionary of Pastoral Care and Counselling (Nashville: Abingdon, 1991) 654-58; Best, Paul and His Converts, 34-57.
} 
you with a rod ( $\left.\dot{\rho} \alpha \dot{\beta} \delta \delta^{\prime}\right)^{\prime} .14$ This explicit warning appears in an implicit fashion in 2 Corinthians where Paul, in a fashion like that of the Jewish paternal tradition, demonstrates father-like manner by confronting, disciplining and testing his spiritual children who had veered from God's will (2 Cor. 2:3-9; 7:8-10; 10:6). Although Paul expected his Corinthian children to be obedient (ínท́коos, 2 Cor. 2:9; $c f$. Pr. 13:1) and a cause for his

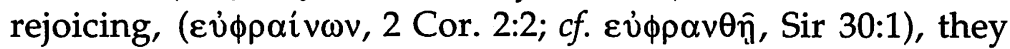
had instead proven 'to be a cause of distress to their spiritual father' (2 Cor. 2:1-4) ${ }^{15}$ because of some form of disobedience.

While many scholars find 2 Corinthians to be 'a sharp letter of rebuke and warning from the apostle',16 F.F. Bruce finds it to be a stinging letter no doubt, but one composed, as Paul himself says, 'out of much affliction and anguish of heart and with many tears' (2 Cor. 2:3-4).17 Although A. Schlatter finds it difficult to believe that Paul's rebuke can be considered an expression of his love, 18 nonetheless Paul's manner shows striking affinity with Proverbs 3:12, Sirach 30:1, and Wisdom of Solomon 11:9-10 when as a father he wrote and confronted his children not out of anger or wrath, but because he loved them. ${ }^{19}$ Paul himself states: 'I wrote... that you might know the

\footnotetext{
${ }^{14}$ On Paul's fatherly function of disciplining, see Best, Paul and his Converts, 87-9; idem, 'Paul's Apostolic Authority', JSNT 27 (1986) 12-18; G.W.H. Lampe, 'Church Discipline and the Interpretation of the Epistle to the Corinthians' in W.R. Farmer (ed.), Christian History and Interpretation Studies presented to John Knox (Cambridge: CUP, 1967) 353-4.

15M.J. Harris, '2 Corinthians' in F.E. Gaebelein (ed.), The Expositor's Bible Commentary (Grand Rapids: Zondervan, 1976) 327.

16M. Dibelius and W.G. Kümmel, Paul (Philadelphia: Westminster, 1966) 96, italics mine. Cf. P.E. Hughes, The Second Epistle to the Corinthians (Grand Rapids: Eerdmans, 1962) 53-4; C.K. Barrett, The Second Epistle to the Corinthians (Peabody: Hendrickson, 1973) 87-8; V.P. Furnish, II Corinthians (New York: Doubleday, 1984) 158-60.

17F.F. Bruce, Paul: Apostle of the Heart Set Free (Grand Rapids: Eerdmans: 1988) 274. For a discussion on the various hypothesis that seek to identify this stinging letter, see R.P. Martin, 2 Corinthians (Waco: Word, 1986) xlvii-xlviii; Harris, '2 Corinthians', 309-11.

${ }^{18}$ A. Schlatter: 'Er schrieb... nichts als einen Verweis seiner Liebe' (Die Korintherbriefe [Stuttgart: Calwer, 1920] 169).

${ }^{19} \mathrm{R}$. Bultmann concurs: 'Und jener Brief, der Schmerz erweckte (wie aus V.4 indirekt, aus 7:8 direkt hervorgeht), ist aus Liebe geschrieben,
} 
abundant love which I have for you' (2:4). Paul might have used one of many words to speak of love here: $\phi i \lambda i \alpha$ or filial love, $\phi i \lambda \alpha v \theta \rho \omega \pi i \alpha$ or benevolent love, $\phi i \lambda o \phi \rho o ́ v \omega \varsigma$ or cordial love, $\phi 1 \lambda \alpha \delta \varepsilon \lambda \phi i \alpha$ or brotherly love. ${ }^{20}$ But instead of any of these, he chose the term $\alpha \gamma \alpha \dot{\pi} \pi \eta$ or self-giving love, ${ }^{21}$ echoing fatherly sages ( $\dot{\alpha} \gamma \alpha \pi \hat{\alpha}, \operatorname{Pr} .3: 12 ; \dot{\alpha} \gamma \alpha \pi \hat{\omega} v$, Sir. 30:1). Since Paul had been badly mistreated by the Corinthians (2:2-4), to continue to seek what was best for them required no ordinary love but one that was willing to look to the interest of others and not of oneself. Like a Jewish fatherly tradition of care, it was this 'sacrificial love' for his children that both tempered and motivated Paul's pastoral correction. ${ }^{22}$ Therefore, to confront the Corinthians when they sinned was not an option for Paul as a parent, but an expression of his pastoral duty to love.

Furthermore, the effects of Paul's disciplining love for the Corinthians initially resulted in their affliction $(2: 2,4 ; 7: 8$ 9). Paul does not attempt to hide this issue, but speaks of the Corinthians' own 'mourning' (7:7), and 'sorrow' (2:2, 5; 7:8-9) that had been caused by him. Rather than avoiding confrontational situations, Paul, like a good Jewish father, appropriately took the hard step of disciplining his children which led to their discomfort and even pain. However, Paul is

nicht aus persönlicher Verstimmtheit und Rachsucht. (Der zweite Brief an die Korinther [Göttingen: Vandenhoeck \& Ruprecht, 1976] 51). So too Martin states: 'love stands in a prominent place in this sentence since it is his deeply felt concern for the church's good and for the individual offender (8-10) that really motivated the letter' (2 Corinthians, 36).

20V.P. Furnish, The Love Command in the New Testament (New York: Abingdon, 1972) 230-31.

${ }^{21}$ A. Nygren: 'Agape, Christian love, is of a wholly different nature. It has nothing to do with desire and longing. It "seeketh not its own", does not ascend, like Eros, to secure advantages for itself, but consists in sacrifice and self-giving' (Agape and Eros: The History of the Christian Idea of Love [Vol. I.2; London: SPCK, 1938] 20). Cf. V.P. Furnish, Theology and Ethics in Paul (Nashville: Abingdon, 1968) 204-06; R. Mohrlang, 'Love' in Dictionary of Paul, 575-78, esp. 577.

22 A. Plummer, Second Epistle of St Paul to the Corinthians (Edinburgh: T. \& T. Clark, 1951) 51. 
not, like the Greco-Roman philosophers, ${ }^{23}$ impassive or distant when he corrects; instead, like the sapiential fathers (Sir. 3:12; 30:5), he is himself distressed and sorrowful (2 Cor. 2:1-4). Yet, it must be understood that the goal of Paul's rebuke was not the alleviation of pain, whether his own or that of the Corinthians. Instead, confrontation was to lead to their 'repentance', which would result in their restored relationship both with God (7:9) and with Paul (7:12). ${ }^{24}$ Thus, Paul's pastoral function of correcting as an act of love, echoing the Jewish tradition, was absolutely necessary for the Corinthians' growth and maturity in the faith, and was a vital part of his pastoral care towards them.

Nonetheless, the overlap between Paul and the GrecoRoman concept of father should not be doubted. The philosopher Epicurus was addressed as 'father' by his community of disciples. ${ }^{25}$ The head of the Roman family was viewed as paterfamilias. ${ }^{26}$ Cicero compared himself with a mild father (Cicero, De domo 94). ${ }^{27}$ Caesar and Augustus were designated with the title, 'Father of the country'.28 And in the religious realm, the gods Saturn, Jupiter, Mars, Neptune and Zeus were frequently addressed as father. ${ }^{29}$ We do not deny that there is congruity between Paul, moral philosophy and the Roman tradition, but seek to stress the likelihood that Paul received his pastoral paternal imagery from his Jewish heritage, where pastoral leaders were depicted in terms of a father whose care for his children includes correction. Paul's

${ }^{23}$ See A.J. Malherbe, 'Paul: Hellenistic Philosopher or Christian Pastor?' ATR 67.1 (1985) 9.

${ }^{24}$ See Martin, 2 Corinthians, 228; F.F. Bruce, 1 and 2 Corinthians (Grand Rapids: Eerdmans, 1990) 218-19.

25Malherbe, 'Paul: Hellenistic Philosopher', 8-11; idem, Paul and the Thessalonians, 40.

26J. Declareuil, Rome the Law-Giver (Westport, Cn.: Greenwood, 1970) 94-5.

27Lassen, 'The Use of the Father Image', 130.

${ }^{28}$ R.M. Grant, History of Rome (New York: Charles Scribner's Sons, 1978) 259-60.

${ }^{29}$ Schrenk, ' $\pi \alpha \tau \eta \rho^{\prime}$ ', 951-53; A. Wlosok, 'Vater und Vorstellungen in der römischen Kultur' in H. Tellenbach (ed.), Das Vaterbild im Abendland (Vol. I; Stuttgart: Kohlhammer, 1978) 38. 
debt to the Old Testament imagery of fatherhood, which influenced Early Judaism, seems to be more significant than has often been recognised.

\section{Conclusion}

Three lessons may be deduced from this short study concerning Paul's role as 'father' in his pastoral practice in Corinth. First, from the picture of pastoral care derived from 2 Corinthians 1 9 , the paternal practice of giving direction in the form of confronting-love seems integral to a Biblical model of care. Second, despite Ernest Best's view that it is impossible... to determine from where Paul derived the image [of fatherhood] in relation to himself', 30 and despite the neglect of scholars to consider Jewish antecedents to Paul's pastoral role as father, the evidence examined above reveals a close affinity between Paul's fatherly correction in 2 Corinthians and that of his Jewish predecessors. Accordingly, Paul's role as father, at least in 2 Corinthians, appears to be best understood along the lines of a Jewish paternal tradition of care. Third, the close affinity between Proverbs 3:12; Sirach 30:1; Wisdom of Solomon 11:910 and 2 Corinthians 2:4 underscores the importance of both the Scriptures and the literature of Early Judaism for the study of the origins of Paul's pastoral practice.

${ }^{30}$ Best, Paul and His Converts, 35. 